\title{
Study of Serum Magnesium Levels in Type 2 Diabetics
}

\author{
Ranjith Kumar GK ${ }^{1}$, Santhosh $\mathbf{P}^{2}$ \\ ${ }^{1}$ Dr Ranjith kumar GK, Junior Resident, Department of General Medicine, Shimoga Institute of Medical Sciences \\ (SIMS), Shimoga, ${ }^{2}$ Dr Santhosh P, Consultant Physician, Kerala Medical College, Mangode, Cherupuiaserry, Palakkad, \\ Kerala.
}

Address for correspondence: Dr Ranjith Kumar G K, Email: ranjithkumargk@gmail.com

\begin{abstract}
Introduction: A prospective case control study of serum magnesium levels in relations with micro \& macro vascular complications of type 2 diabetes mellitus in J.L.N Hospital Ajmer. Methods: 25 patients of type 2 diabetes mellitus admitted to J.L.N Hospital were included in the study. Also 25 non diabetic patients admitted at the same time were included in the study under the control group. Results: The present study had diabetic patients ranging from 40-80 years. The mean serum magnesium levels were $1.68 \mathrm{mg} / \mathrm{dl}$ and $2.02 \mathrm{mg} / \mathrm{dl}$ in cases and controls respectively. The mean serum magnesium levels in patients on insulin, OHAs and on OHAs plus insulin were $1.43 \mathrm{mg} / \mathrm{dl}, 2.14 \mathrm{mg} / \mathrm{dl} \mathrm{and} 1.53 \mathrm{mg} / \mathrm{dl}$ respectively. The mean serum magnesium levels in patients with controlled diabetes were $2 \mathrm{mg} / \mathrm{dl}$ and $1.33 \mathrm{mg} / \mathrm{dl}$ in patients with uncontrolled diabetes. The mean serum magnesium levels in patients with and without diabetic retinopathy were $1.44 \mathrm{mg} / \mathrm{dl}$ and $2.11 \mathrm{mg} / \mathrm{dl}$ respectively. Whereas the mean serum magnesium levels in patients with diabetic nephropathy were $1.31 \mathrm{mg} / \mathrm{dl}$ and $2.08 \mathrm{mg} / \mathrm{dl}$ in those without nephropathy. Conclusion: Hypomagnesemia is a factor in type 2 diabetes and associated with various complications and duration of diabetes leading to various complications. Hence it is worth measuring serum magnesium levels in patients with type $2 \mathrm{DM}$ and probably correlates their relationship with various complications.
\end{abstract}

\section{Introduction}

Diabetes mellitus (DM) refers to a group of common metabolic disorders that share the phenotype of hyperglycemia. Several distinct type of DM is caused by a complex interaction of genetics and environmental factors. Depending upon the etiology of the DM, factors contributing to hyperglycemia include reduced insulin secretion, decreased glucose utilization, and increased glucose production. The metabolic deregulation associated with DM causes secondary pathophysiologic changes in multiple organ systems, leading to microvascular (retinopathy, nephropathy, neuropathy) and macrovascular (coronary heart disease, peripheral arterial disease, cerebrovascular disease)[1].

Low magnesium status has repeatedly been demonstrated in patients with type 2 diabetes. Magnesium deficiency appears to have a negative impact on glucose homeostasis and insulin sensitivity in patients with type 2 diabetes [2].

Manuscript received: $1^{\text {st }}$ July 2015

Reviewed: $8^{\text {th }}$ July 2015

Author Corrected: $19^{\text {th }}$ July 2015

Accepted for Publication: $31^{\text {st }}$ July 2015
Magnesium deficiency has been found to be associated with microvascular and macrovascular diseases in diabetes. Hypomagnesemia has been demonstrated in patients with diabetic retinopathy, lower levels of magnesium predicting a greater risk for diabetic retinopathy. Magnesium depletion has also been associated with arrhythmogenesis, vasospasm, platelet activity and hypertension [3].

25 to $39 \%$ of outpatient diabetics have low concentrations of serum magnesium[4] and numerous studies have shown lower serum magnesium concentrations in type 2 diabetics compared to healthy controls[5,6]. The reasons why magnesium deficiency occurs in diabetes are not clear, but may include increased urinary loss, lower dietary intake, or impaired absorption of magnesium compared to healthy individuals [7]. Several studies have reported increased urinary magnesium excretion in type 1 and 2 diabetes $[8,9,10,11]$ some reporting a correlation between glycemic control and urinary magnesium loss [10]. 
Magnesium is involved in insulin secretion, binding and activity. Cellular deficiency of magnesium can alter the membrane bound sodium-potassium-adenosine triphosphatase which is involved in maintaining the gradient of sodium and potassium and also in glucose transport [12].

The present study was undertaken with an aim to correlate serum magnesium levels with micro and macrovascular complications of diabetes - retinopathy, nephropathy, neuropathy and ischemic heart disease and peripheral vascular disease

\section{Objectives}

1. To compare the levels of serum magnesium in patients with type 2 diabetes mellitus and normal healthy individuals.

2. To study levels of serum magnesium in controlled and uncontrolled diabetics.

3. To study levels of serum magnesium in relations with micro \& macro vascular complications of type 2 diabetes mellitus.

\section{Materials and Methods}

\section{Source of data:}

25 patients of type 2 diabetes mellitus admitted to J.L.N Hospital were included in the study. Also 25 non diabetic patients admitted at the same time were included in the study under the control group.

\section{Method of collection of data: (including sampling procedures if any)}

Patients were considered to be diabetic based on WHO criteria [13] for diagnosis of diabetes mellitus which is

1) Symptoms of diabetes mellitus plus a random glucose concentration $>200 \mathrm{mg} / \mathrm{dl}$ (11.1mmol/l). The classic symptoms of diabetes mellitus include polyuria, polydypsia and unexplained weight loss

OR

2) Fasting blood glucose $>126 \mathrm{mg} / \mathrm{dl}(7.0 \mathrm{mmol} / \mathrm{l})$. Fasting is defined as no caloric intake for at least 8 hours.
3) 2 hour post prandial glucose $>200 \mathrm{mg} / \mathrm{dl}$. Among diabetics, the above criteria were considered to be included for the study.

\section{Inclusion criteria for case selection:}

1) Urine sugar-positive

2) Fasting blood sugar $>126 \mathrm{mg} / \mathrm{dl}$

3) Post Prandial blood sugar $>200 \mathrm{mg} / \mathrm{dl}$

\section{Exclusion criteria for case selection:}

Patients excluded from this study were those diabetics who had associated

1. Hypertension,

2. Gastrointestinal disorders,

3. Impaired renal function,

4. Alcoholism,

5. Pancreatitis,

6. Other endocrinal disorders and

7. Those on diuretic therapy, aminoglycosides and iatrogenic administration.

Those patients who had persistent FBS levels >126 mg $\%$ in spite of therapy during hospital stay will be grouped as uncontrolled diabetics.

Inclusion criteria for controls: Age and sex matched non diabetic patients admitted in the hospital were taken as controls after applying the same exclusion criteria which were applied for the cases.

\section{Estimation of serum magnesium:}

Colorimetric method using calmagite dye:

\section{Normal values}

Adults: $1.3-2.5 \mathrm{mEq} / \mathrm{L}$

Children: $1.4-1.9 \mathrm{mEq} / \mathrm{L}$

New born: $1.5-2.3 \mathrm{mEq} / \mathrm{L}$

Statistical method: T-test has been used to find the significance of mean pattern of serum magnesium between cases/controls, Insulin/OHAs and controlled/uncontrolled. ANOVA was used to find the mean pattern of serum magnesium in different complications, in different range of FBS.

OR

\section{Results}

Study Design: A Comparative study consisting of 25 Diabetic Mellitus patients and 25 controls was undertaken to investigate the change pattern of serum magnesium in DM cases when compared to controls. 
Table 1: Age distribution

\begin{tabular}{|l|l|l|l|l|}
\hline \multirow{2}{*}{ Age in years } & Cases & Controls & \multicolumn{2}{l|}{} \\
\cline { 2 - 5 } & Number & \% & Number & \% \\
\hline $41-50$ & 6 & 24.0 & 7 & 28.0 \\
\hline $51-60$ & 9 & 36.0 & 8 & 32.0 \\
\hline $61-70$ & 7 & 28.0 & 6 & 24.0000 \\
\hline $71-80$ & 3 & 12.0 & 3 & 12.0 \\
\hline$>80$ & - & - & 1 & 4.0 \\
\hline Total & 25 & 100.0 & 50 & 100.0 \\
\hline Mean \pm SD & $58.16 \pm 10.35$ & & $58.76 \pm 11.36$ & \\
\hline
\end{tabular}

The mean age of the diabetics was $58.16 \pm 10.35$ years whereas it was $58.76 \pm 12.84$ years in controls. The maximum number of patients was in the age group of 51-60 i.e. $34 \%$.

Table 2: Sex Distribution

\begin{tabular}{|l|l|l|l|l|}
\hline \multirow{2}{*}{ Sex } & Cases & Controls & \multicolumn{2}{l|}{} \\
\cline { 2 - 5 } & Number & \% & Number & \% \\
\hline Male & 14 & 56.0 & 14 & 56.0 \\
\hline Female & 11 & 44.0 & 11 & 44.0 \\
\hline Total & $\mathbf{2 5}$ & $\mathbf{1 0 0 . 0}$ & $\mathbf{2 5}$ & $\mathbf{1 0 0 . 0}$ \\
\hline
\end{tabular}

Both among the cases and controls the sex distribution was same i.e. $56 \%$ and $44 \%$ males and females respectively.

There was no significant difference between cases and controls with respect to serum creatinine levels. The mean serum creatinine levels among cases and controls were $0.93 \pm 0.27$ and $0.96 \pm 0.25 \mathrm{mg} / \mathrm{dl}$ respectively. The mean FBS levels among cases and controls were $216.36 \mathrm{mg} / \mathrm{dl}$ and $93.24 \mathrm{mg} / \mathrm{dl}$ respectively. The mean serum magnesium levels in cases and controls is $1.67 \mathrm{mg} / \mathrm{dl}$ and $2.02 \mathrm{mg} / \mathrm{dl}$ with a $\mathrm{P}$ value of $<0.001$, which is statistically significant. Although the exact reason in not known, this could probably be explained on the basis of increased urinary loss, low dietary intake or impaired absorption of magnesium in diabetic patients.

Hypomagnesaemia was seen in $48 \%$ of the cases where as only $4 \%$ of the controls had Hypomagnesemia.

Figure 1

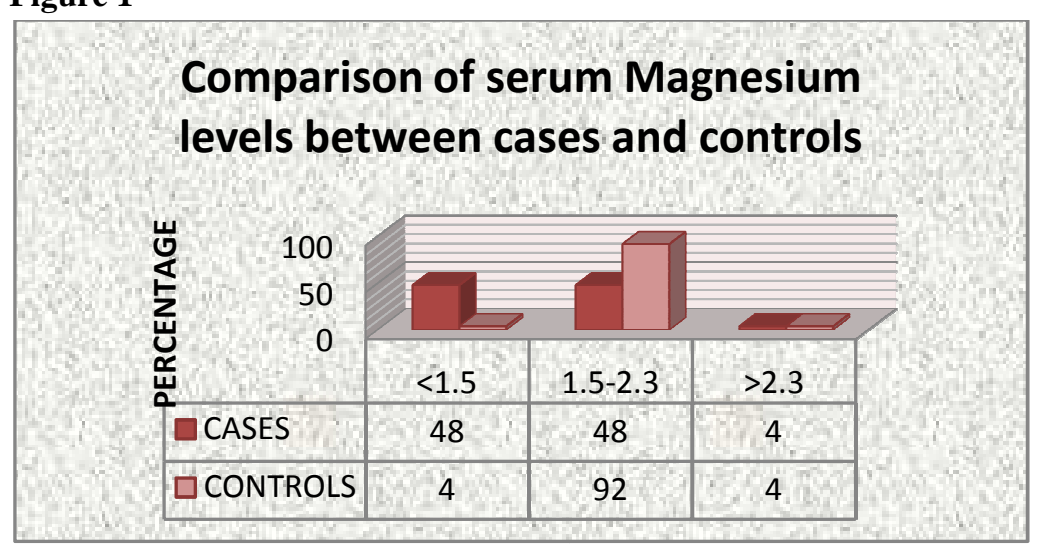

Table 3: Effect of level of control of DM on serum Magnesium

\begin{tabular}{|l|l|l|}
\hline Serum magnesium & Controlled $(\mathrm{n}=13)$ & Uncontrolled $(\mathrm{n}=12)$ \\
\hline Range $($ Min-Max $)$ & $1.1-2.5$ & $1-1.9$ \\
\hline Mean \pm SD & $2.00 \pm 0.39$ & $1.33 \pm 0.23$ \\
\hline $95 \%$ CI & $1.79-2.21$ & $1.2-1.46$ \\
\hline P value $<0.0001$ & \multicolumn{2}{|l}{} \\
\cline { 1 - 2 } & &
\end{tabular}


The mean serum magnesium levels among patients with uncontrolled diabetes were lower as compared to patients with controlled diabetes, which was statistically significant ( $\mathrm{P}$ value $<0.0001$ ). Hyperglycemia directly causes suppression of magnesium.

\section{Table 4: Effect of type of treatment on Serum magnesium}

\begin{tabular}{|l|l|l|l|}
\hline Serum Magnesium & Insulin $(\mathrm{n}=12)$ & OHA $(\mathrm{n}=8)$ & INSULIN+OHA $(\mathrm{n}=5)$ \\
\hline Range (Min-Max) & $1.0-2.10$ & $1.40-2.50$ & $1.3-2.10$ \\
\hline Mean \pm SD & $1.43 \pm 0.33$ & $2.13 \pm 0.33$ & $1.53 \pm 0.34$ \\
\hline 95\% CI & $1.24-1.62$ & $1.90-2.36$ & $1.23-1.83$ \\
\hline Significance & $\mathrm{P}<0.001$ & \multicolumn{2}{|l}{} \\
\cline { 1 - 2 }
\end{tabular}

Of the total of 25 diabetic patients, 12(48\%) were on insulin alone, 8(32\%) were on OHA'S and 5(20\%) were on combination of OHA'S and insulin. The mean serum magnesium levels in the insulin group, OHA group and the insulin+ OHA group were $1.43 \mathrm{mg} / \mathrm{dl}, 2.13 \mathrm{mg} / \mathrm{dl}$ and $1.53 \mathrm{mg} / \mathrm{dl}$ respectively. The serum magnesium levels were significantly lower in the insulin treated group compared to the OHA treated group. This may be because, Insulin causes shift of magnesium from extracellular to intracellular compartment causing low serum magnesium levels.

Infections were the most common cause for admission accounting for 52\% of admissions among diabetics. The next most common cause was neurological problems accounted for $20 \%$ of admissions, 3 patients were admitted for stroke, 1 patient with peripheral neuropathy and 1 patient with cranial nerve palsy.

Cardiovascular events were accounting for 3 admissions. Of the cardiovascular diseases 2 were admitted with unstable angina and 1 with myocardial infarction.

Peripheral vascular diseases accounted for $8 \%$ of admissions. 1 patient had gangrene and 1 patient had ischemic signs in the limbs. $8 \%$ of patients were admitted exclusively for uncontrolled sugars.

Patients with diabetic retinopathy and hypomagnesaemia were more as compared to patients without retinopathy (36\% vs $12 \%)$. Hypomagnesaemia and increased serum cholesterol and triglyceride levels are responsible for microvascular changes in diabetes leading to retinopathy [14]. Mean serum magnesium levels in patients with and without diabetic retinopathy was $1.44 \mathrm{mg} / \mathrm{dl}$ and $2.11 \mathrm{mg} / \mathrm{dl}$ respectively, showing that patients with diabetic retinopathy had significantly low levels of serum magnesium as compared to those without diabetic retinopathy (P value $<0.0001)$.

The mean serum magnesium levels in patients with and without diabetic nephropathy were $1.31 \mathrm{mg} / \mathrm{dl}$ and $2.08 \mathrm{mg} / \mathrm{dl}$ respectively which were statistically significant $(\mathrm{P}$ value $<0.0001)$. The mean serum magnesium levels in patients with diabetic neuropathy was

$1.69 \mathrm{mg} / \mathrm{dl}$ and in those without neuropathy was $1.67 \mathrm{mg} / \mathrm{dl}$ which was statistically not significant $(\mathrm{P}$ value $<0.1)$.The mean serum magnesium levels in patients with IHD and those without IHD were $1.57 \mathrm{mg} / \mathrm{dl}$ and $1.78 \mathrm{mg} / \mathrm{dl}$ respectively which was statistically not significant $(\mathrm{P}$ value $<0.24) .2$ patients with peripheral vascular disease, among which 1 patient had hypomagnesaemia. Due to small number of subjects comparison was not possible.

Table 5: Serum magnesium levels in comparing all the complications

\begin{tabular}{|l|l|l|l|}
\hline Serum Magnesium & Complication $(\mathrm{n}=5)$ & Complications $(\mathrm{n}=9)$ & All three $(\mathrm{n}=6)$ \\
\hline Mean \pm SD & $2.13 \pm 0.30$ & $1.39 \pm 0.31$ & $1.35 \pm 0.29$ \\
\hline $95 \%$ CI & $1.89-2.46$ & $1.17-1.61$ & $1.08-1.62$ \\
\hline
\end{tabular}

$20 \%$ of the diabetic patients had one complication. Mean serum magnesium levels among patients with only one complication was $2.13 \mathrm{mg} / \mathrm{dl}$ and among them $8 \%$ had retinopathy, $0 \%$ had nephropathy and $12 \%$ had neuropathy.

$36 \%$ of the diabetic patients had two complications. Mean serum magnesium levels among patients with two 
complications was $1.39 \mathrm{mg} / \mathrm{dl}$ and among them $24 \%$ had retinopathy with nephropathy, $8 \%$ had retinopathy with neuropathy and $4 \%$ had neuropathy with nephropathy.

$24 \%$ of the diabetic patients had all the three complications and their mean serum magnesium level was $1.35 \mathrm{mg} / \mathrm{dl}$.

Table 6: Serum magnesium levels in comparison to duration of diabetes

\begin{tabular}{|c|c|c|c|c|}
\hline Serum Magnesium & $0-5$ years $(n=6)$ & $6-10$ years $(n=12)$ & $11-15$ years $(n=4)$ & $16-20$ years $(n=3)$ \\
\hline Mean \pm SD & $1.8 \pm 0.57$ & $1.62 \pm 0.42$ & $1.70 \pm 0.55$ & $1.67 \pm 0.55$ \\
\hline $95 \%$ CI & $1.39-2.21$ & $1.33-1.91$ & $0.99-2.40$ & $0.89-2.48$ \\
\hline
\end{tabular}

Mean serum magnesium levels according to the duration of diabetes i.e.0-5, 6- 10, 11-15, 16-20 years were 1.8, $1.62,1.7$ and $1.67 \mathrm{mg} / \mathrm{dl}$ respectively.

\section{Discussion}

The present study included 25 type 2 diabetic patients and 25 control subjects. Serum magnesium levels were determined in all these subjects.

The present study had diabetic patients ranging from $40-80$ years. The average age of controls in the present study was 58.76 years while in the study of Yajnik et al it was 46.5 years [15]. The mean age of patients on insulin and non insulin treated diabetics was 57.6 years and 58.61 years respectively, Other studies have similar results [15].

The percentage of patients in the insulin treated diabetic group who were men was $24 \%$ in both the present study as well as the study done by C.S. Yajnik et al. The percentage of men in the non insulin treated diabetic group was $32 \%$ and $76 \%$ in the present study and the study conducted by C.S. Yajnik et al respectively.

In our study serum magnesium levels were recorded in controls is $2.02 \pm 0.25$, in various other studies levels in controls varied from $2.07 \pm 0.27$ to $2.30 \pm 0.32$ [5,16,17]. In diabetics patients in our study it is $1.68 \pm 0.46$ in other studies it varied from $1.8 \pm 0.22$ to $1.94 \pm 0.05[5,16,17]$, which was statically significant.

Jain et al [16] selected 85 cases, which included 20 comparable healthy adults and 65 diabetics of whom 50 diabetics were without apparent renal involvement.

On establishing the relationship between magnesium levels and the state of control of diabetes, it was observed that in poorly controlled diabetic's serum magnesium levels were lower than that of fairly controlled diabetics. These results were comparable with the study done by Jain et al $(1.85 \pm 0.08$ in well controlled v/s $1.68 \pm 0.12$ in poorly controlled). Serum magnesium levels in diabetics getting insulin therapy $(1.43 \pm 0.33)$ was lower than those getting OHA'S $(2.13 \pm 0.33)$, these results were comparable with study done by Jain et al $(1.59 \pm 0.13$ in the insulin treated $\mathrm{v} / \mathrm{s}$ $1.90 \pm 0.18$ in the OHA treated subjects).

Nadler JL et al[4] evaluated intracellular (erythrocytic) $\mathrm{Mg}^{2+}$ concentration in 20 type 2 diabetics. In addition, effects of intravenous 3-h drip or 8 weeks of oral magnesium supplementation on intracellular $\mathrm{Mg}^{2+}$ concentration levels and platelet reactivity was studied. The results showed intracellular $\mathrm{Mg}^{2+}$ concentration of diabetic patients was significantly reduced compared with values in non diabetic control subjects.

However the present study did not include evaluating the effects of oral or IV magnesium supplementation. Nagase $\mathrm{N}$ et al [17] studied the interrelationships between hypertension, ischemic heart disease and diabetes mellitus.

They also concluded that serum magnesium level of poorly controlled diabetic patients is lower than that of well controlled diabetic patients. These results suggested that magnesium deficient state is one of the causes of insulin resistance. Comparison of serum magnesium levels between well controlled and poorly controlled diabetics had a positive correlation with the present study.

Dipankar Kundu et al(2013)[18] compared of 30 type 2 diabetic patients without retinopathy, 30 type 2 diabetic patients with retinopathy in the age group 45-75 years as cases and 60 age and sex matched healthy individuals as controls . Hypomagnesemia was observed in cases with both type 2 diabetic patients 
without retinopathy $(2.02 \pm 0.29)[18] \mathrm{v} / \mathrm{s}$ present study $(1.98 \pm 0.42)$ and in type 2 diabetic patients with retinopathy $(1.38 \pm 0.39)[18] \mathrm{v} / \mathrm{s}$ present study $(1.51 \pm$ $0.41)$, when compared with controls $(2.62 \pm 0.36)[18]$ v/s present study $(2.03 \pm 0.25)$.

Prabodh S et al [19] studied Status of copper and magnesium levels in diabetic nephropathy cases. The study investigated the status of copper and magnesium in diabetic nephropathy cases to establish a possible relation. Forty patients of diabetic nephropathy participated in the study as cases. Forty age- and sexmatched healthy individuals served as controls. The mean magnesium levels of cases $(1.60 \pm 0.32 \mathrm{meq} / \mathrm{L})$ were significantly lower than controls $2.14 \pm 0.16$ meq/L $(\mathrm{p}<0.05)$. But the mean copper levels of cases, $165.42 \pm 5.71 \mu \mathrm{g} / \mathrm{dl}$, shows no significant difference with controls, $166.6 \pm 5.48 \mu \mathrm{g} / \mathrm{dl}$, $(\mathrm{p}>0.05)$.

In the present study the mean serum magnesium levels in patients with and without diabetic nephropathy were $1.31 \mathrm{mg} / \mathrm{dl}$ and $2.08 \mathrm{mg} / \mathrm{dl}$ respectively which were statistically significant ( $\mathrm{P}$ value $<0.0001$ ).

There was no scope for follow up in the present study. Hence change in magnesium states with respect to improvement or worsening of diabetic state in the long run was not studied. This study focuses on estimating magnesium levels in type 2 diabetics at a given point (during admission) but not on therapeutically correcting hypomagnesemia or otherwise (not correcting) in the future course of the disease and its outcome

\section{Conclusion}

These results suggested that magnesium deficient state is one of the causes of insulin resistance. Hypomagnesemia was associated with diabetic retinopathy and diabetic nephropathy. No correlation was found in respect to Neuropathy \& IHD. More the duration of diabetes and the levels of FBS, lower were the serum magnesium levels. Hypomagnesemia is a factor in type 2 diabetes and associated with various complications. Hence it is worth measuring serum magnesium levels in patients with type 2DM and probably correlates their relationship with various complications.

Funding: Nil

Conflict of interest: Nil

Permission from IRB: Yes

\section{Bibliography}

1. Alvin C.P Harrison's Principles of Internal Medicine. $18^{\text {th }}$ Edition. McGraw-Hill. 2012.

2. Nadler JL, Buchanan T, Natarajan R, Antonipillai I, Bergman R \& Rude RMagnesium deficiency produces insulin resistance and increased thromboxane Synthesis. Hypertension 1993 Jun;21(6 Pt 2):1024-9.

3. Sasaki S, Oshima T, Mtsuura H, et al. Abnormal magnesium status in patients with cardiovascular diseases. Clin Sci (Lond). 2000 Feb;98(2):175-81.

4. Nadler JL \& Rude RK. Disorders of magnesium metabolism. Endocrinol Metab Clin North Am. 1995 Sep;24(3):623-41.

5. Nadler JL, Malayan S, Luong H, Shaw S, Natarajan RD \& Rude RK. Intracellular free magnesium deficiency plays a key role in increased platelet reactivity in type II diabetes mellitus. Diabetes Care. 1992 Jul;15(7):835-41.

6. Ma J, Folsom AR, Melnick SL, Eckfeldt JH, Sharrett AR, Nabulsi AA, Hutchinson RG \& Metcalf PA. Associations of serum and dietary magnesium with cardiovascular disease, hypertension, diabetes, insulin, and carotid arterial wall thickness: the ARIC study. Atherosclerosis Risk in Communities Study. J Clin Epidemiol. 1995 Jul;48(7):927-40.

7. Monika KW, Michael BZ, Giatgen AS, Richard FH, Low plasma magnesium in type 2 diabetes. Swiss Med Wkly. 2003 May 17;133(19-20):289-92.

8. Johannson G, Danielson BG, Ljunghall S \& Wibell L. Evidence for a disturbed magnesium metabolism in diabetes- mellitus. Magnes Bull 1981; 2: 178-180.

9. Fujii S, Takemura T, Wada M, Akai T \& Okuda K. Magnesium levels in plasma, erythrocyte and urine in patients with diabetes mellitus. Horm Metab Res. 1982 Mar;14(3):161-2

10. McNair P, Christensen MS, Christiansen C, Madsbad S \& Transbol I. Renal Hypomagnesaemia in human diabetes mellitus: its relation to glucose homeostasis. Eur J Clin Invest. 1982 Feb;12(1):81-5

11. Sjögren A, Floren $\mathrm{CH} \&$ Nilsson A. Magnesium, potassium and zinc deficiency in subjects with type II diabetes mellitus. Acta Med Scand. 1988;224(5):461-6. 
12. Paolisso G, Scheen A, D' Onfrio F, Lefebvre P. Magnesium and glucose. Diabetologia. 1990 Sep;33(9):511-4.

13. Definition and diagnosis of diabetes mellitus and intermediate hyperglycemia : report of a WHO/IDF consultation. 2006;1:12.

14. Ishrat K, SA Jaweed, JS Bardapukar, VP Patil. Study of magnesium, glycosylated haemoglobin and lipid profile in diabetic retinopathy. Indian $\mathrm{J}$ Clin Biochem. 2004 Jul;19(2):124-7.

15. Yajnik CS, Smith RF, Hockaday TD, Ward NI, Fasting plasma magnesium concentrations and glucose disposal in diabetes. Br Med J. 1984 April; 288(6423): 1032-34.
16. Jain AP, Gupta NN, Kumar A, Some metabolic facets of magnesium in diabetes mellitus. J Assoc Physicians India. 1976 Dec;24(12):827-31.

17. Nagase $\mathrm{N}$ et al. Hypertension and Serum $\mathrm{Mg}$ in the Patients with Diabetes and Coronary Heart Disease: Hypertens Res. 1996 Jun;19 Suppl 1:S65-8.

18. Dipankar Kundu et al, Serum magnesium levels in patients with diabetic Retinopathy, J Nat Sci Biol Med. 2013 Jan;4(1):113-6.

19. S. Prabodh et al, Status of Copper and Magnesium Levels in Diabetic Nephropathy Cases: a Case-Control Study from South India: Biol Trace Elem Res. 2011 Jul;142(1):29-35.

\section{How to cite this article?}

Ranjith Kumar GK, Santhosh P. Study of Serum Magnesium Levels in Type 2 Diabetics. Int J Med Res Rev 2015;3(7):699-705. doi: 10.17511/ijmrr.2015.i7.132. 